\title{
ПОТЕНЦІАЛ РОЗВИТКУ ТРАНСПОРТНОГО СЕКТОРУ УКРАЇНИ
}

\author{
Лаврова-Манзенко О. О., \\ к.е.н., дочент кафедри економіки підприємств, обліку і аудиту Черкаський національний \\ університет ім. Б. Хмельницьького, м. Черкаси, Україна \\ DOI: https://doi.org/10.31435/rsglobal_conf/25112020/7243
}

\begin{abstract}
Composition of a transport system is analysed in the article, it 's distinguished key elements and intercommunications between them. An author investigates the basic world indexes of estimation of development of a transport system of Ukraine and it's separate constituents, determines the place of Ukraine in a world transport environment. Author describes the volumes of freight transportations in Ukraine after the types of it and their dynamics. As a result the basic problems of development of a transport industry, their reason and consequences are certain in the article. The analysis of the governmental programs and strategies of development transport allowed to set forth own vision of key events of realization of existent potential. The article is sanctified to not only illumination of existent development of a transport industry status, and to the exposure of it's fundamental problems and ways of their overcoming.
\end{abstract}

Keywords: transport, index, development, transport infrastructure, prospects, logistic.

Постановка проблеми (вступ). Особливість геопросторового розташування України полягає в тому, що територія країни $є$ дуже великою та може слугувати зручним транспортним хабом між Азією та Європою, котрий забезпечений усіма видами транспорту: морським, залізничним та авіаційним. При цьому, найбільший та найпотужніший у світі транспортний літак Ан-225 «Мрія» (не зважаючи на Stratolaunch Model 351, котрий поки що має космічне призначення) розроблений та виготовляється саме в Україні. Транспортний потенціал залізничної мережі України на Євразійському континенті перевершують лише Китай, Індія та Росія. Автомобільні дороги України з'єднують Східну і Західну Європу, країни Балтії з Чорноморським регіоном. На території України є 18 морських портів високої пропускної потужності (5 з яких знаходяться на тимчасово окупованій території АР Крим), деякі з яких входять до маршрутів океанських сервісів. Потенціал трубопровідного транспорту України $\epsilon$ колосальним, але історично спрямований на співпрацю 3 країною-агресором - Росією. Зважаючи на політичну ситуацію, даний сектор транспорту нами не розглядався. Однак, незважаючи на колосальний, на перший погляд, потенціал стан транспортної галузі потребує докорінної модернізації.

Мета дослідження полягає у дослідженні сучасного стану транспортної галузі України та окреслення економічних перспектив ії розвитку.

Методи дослідження використано як загальнонаукові, так і специфічні. Для встановлення сучасного стану транспортної галузі України використано переважно монографічний метод, що дозволив проаналізувати існуючі рейтинги

Результати дослідження. Оцінити рівень розвитку транспортних підприємств цілої країни на тлі інших можуть допомогти міжнародні рейтинги та індекси. Так, Всесвітній економічний форум. Як міжнародна неурядова організація (Женева) постійно публікує власне бачення розвитку окремих країн - Глобальний індекс конкурентоспроможності, розрахунок котрого грунтується н авторських методиках та офіційних статистичних даних, результатів глобального опитування керівників компаній - великого щорічного дослідження, яке проводиться форумом разом з мережею партнерських організацій - провідних дослідницьких інститутів і організацій у країнах, аналізованих у звіті. Результати розрахунку глобального індексу конкурентоспроможності вже давно створили свій власний авторитет та активно використовуються науковцями. У його складі є субіндекс - інфраструктура, а у його складі елементи розвитку транспортних підприємств та їх бізнес-середовища.

За субіндексом «Транспортна інфраструктура» індексу Глобальної конкурентоспроможності Україна посіла 59 місце із 141 країни, що включені до цього дослідження. Рейтинг індексів складений у бальних оцінках за якими показники України $(55,5$ балів) є близькими до рівня розвитку транспортної інфраструктури таких країн як Нова Зеландія, Естонія, Кіпр та Румунія (рис. 1). 


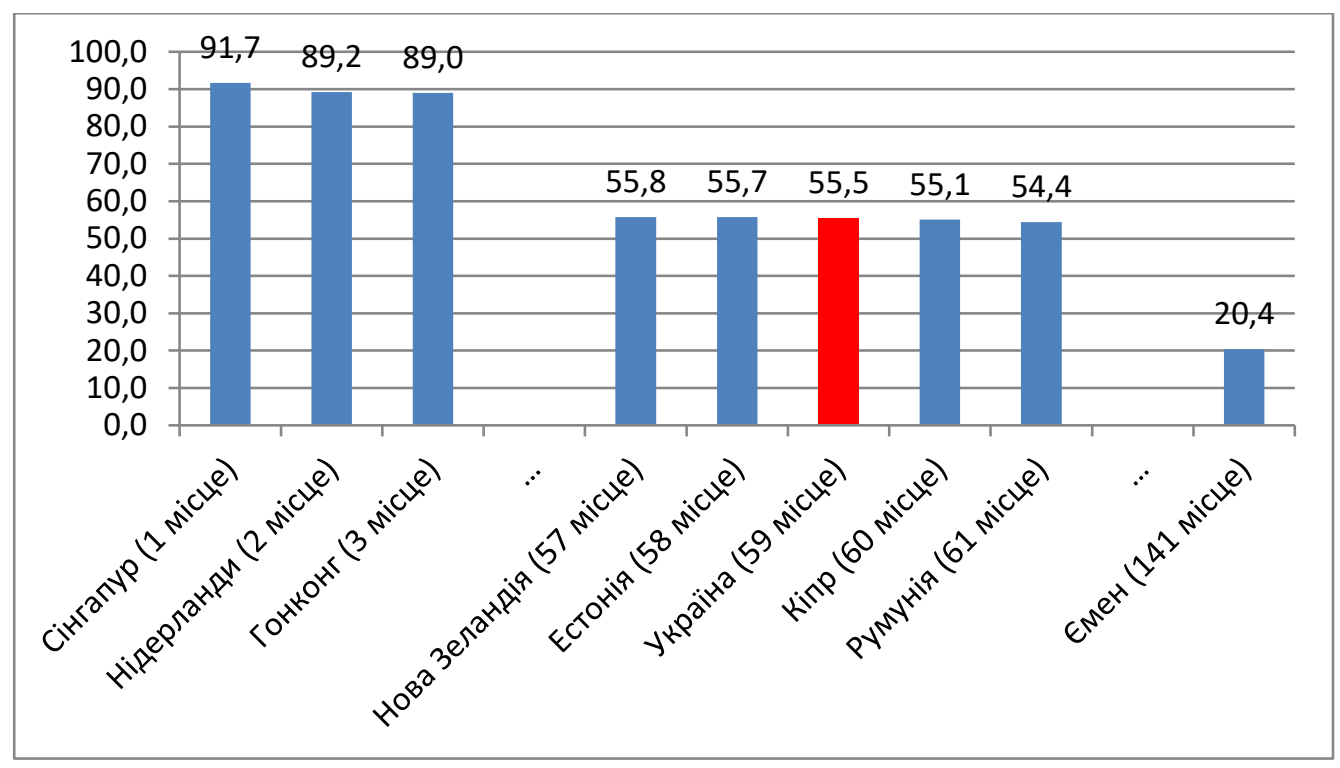

Рис. 1. Показник розвитку інфраструктури в індексі глобальної конкурентоспроможності 2019p, бали. Джерело: складено автором за даними Global Competitiveness Index 2019 [1]

Складовими інфраструктури в частині транспорту з позиції Всесвітнього економічного форуму є розвиток якості доріг, портової, залізничної та авіаційної інфраструктури. В частині якості доріг Україну віднесено до рівня розвитку автошляхів таких країн як Молдова, Нігерія та Парагвай та в цілому присвоєно 130 місце. Показники оцінки стану розвитку портової та авіаційної інфраструктури також дуже низькі - 93 та 92 місце відповідно. Рівень розвитку залізничної інфраструктури оцінено достатньо високо - 37 позиція. Поруч з такими країнами як Італія, Австралія та Норвегія. Але основою такого високого показника $\epsilon$ протяжність залізничних доріг, кількість депо та вагоноремонтних заводів, а не якість перевезень, нажаль.

В цілому, рейтингові показники оцінки транспорту в Україні варто розглядати в динаміці та у порівнянні з іншими країнами-учасницями ринку. Для порівняння нами обрано такі країни: Росія - як країна 3 найбільшою площею у світі, а тому визначальною роллю розвитку транспорту; Польща - як найближчий сусід та країна частково пострадянського простору, котра значно раніше обрала шлях євроінтеграції; Литва - як країна орієнтир соціально-економічного розвитку для України; Грузія - як країна партнер та країна, що перебуває у схожих політичних умовах та має деякі спільні риси геопросторового положення; Румунія - як країна, котра вважається наступницею українських реформ в напрямку євроінтеграції; Туреччина - як країна, що територіально є транспортною альтернативою України у багатьох випадках світового трафіку. Нами опрацьовано показники розвитку транспорту за період в п’ять років за всіма вказаними країнами (табл. 1).

Таблиця 1. Динаміка рейтингових оцінок розвитку транспорту як складової індексу глобальної конкурентоспроможності, місце

\begin{tabular}{|c|c|c|c|c|c|}
\hline \multirow{2}{*}{ Країна } & \multicolumn{5}{|c|}{ Міце в рейтингу } \\
\cline { 2 - 6 } & $2014-2015$ & $2015-2016$ & $2016-2017$ & $2017-2018$ & $2018-2019$ \\
\hline 1 & 2 & 3 & 4 & 5 & 6 \\
\hline \multicolumn{7}{|c|}{ Вся інфраструктура } \\
\hline Литва & 43 & 42 & 45 & 47 & 39 \\
\hline Туреччина & 51 & 53 & 48 & 53 & 49 \\
\hline Грузія & 59 & 61 & 65 & 69 & 73 \\
\hline Польща & 63 & 56 & 53 & 44 & 25 \\
\hline Україна & 68 & 69 & 75 & 78 & 57 \\
\hline Румунія & 85 & 86 & 88 & 83 & 55 \\
\hline Росія & 97 & 35 & 35 & 35 & 50 \\
\hline \multicolumn{7}{|c|}{ Якість доріг } \\
\hline Литва & 36 & 33 & 28 & 30 & 24 \\
\hline
\end{tabular}


Продовження таблиці 1.

\begin{tabular}{|c|c|c|c|c|c|}
\hline 1 & 2 & 3 & 4 & 5 & 6 \\
\hline Туреччина & 40 & 36 & 36 & 37 & 31 \\
\hline Грузія & 65 & 73 & 72 & 65 & 81 \\
\hline Польща & 89 & 76 & 78 & 82 & 57 \\
\hline Украӥна & 139 & 139 & 134 & 130 & 114 \\
\hline Румунія & 121 & 120 & 123 & 114 & 119 \\
\hline Росія & 124 & 123 & 128 & 120 & 99 \\
\hline \multicolumn{6}{|c|}{ Розвиток портів } \\
\hline Литва & 47 & 38 & 33 & 39 & 38 \\
\hline Туреччина & 57 & 53 & 52 & 54 & 44 \\
\hline Грузія & 67 & 67 & 66 & 64 & 85 \\
\hline Польща & 78 & 73 & 71 & 66 & 51 \\
\hline Украӥна & 107 & 108 & 98 & 93 & 78 \\
\hline Румунія & 104 & 96 & 96 & 92 & 76 \\
\hline Росія & 81 & 75 & 72 & 69 & 47 \\
\hline \multicolumn{6}{|c|}{ Залізничний транспорт } \\
\hline Литва & 22 & 23 & 24 & 23 & 22 \\
\hline Туреччина & 49 & 51 & 49 & 45 & 56 \\
\hline Грузія & 33 & 35 & 38 & 39 & 43 \\
\hline Польща & 55 & 53 & 55 & 57 & 45 \\
\hline Украӥна & 25 & 24 & 25 & 27 & 34 \\
\hline Румунія & 59 & 62 & 79 & 73 & 76 \\
\hline Росія & 26 & 28 & 34 & 37 & 17 \\
\hline \multicolumn{6}{|c|}{ Авіаційний транспорт } \\
\hline Литва & 75 & 77 & 65 & 59 & 57 \\
\hline Туреччина & 34 & 33 & 29 & 31 & 31 \\
\hline Грузія & 84 & 83 & 72 & 68 & 86 \\
\hline Польща & 86 & 90 & 88 & 69 & 61 \\
\hline Украӥна & 99 & 97 & 101 & 89 & 101 \\
\hline Румунія & 105 & 106 & 103 & 89 & 71 \\
\hline Росія & 79 & 81 & 69 & 66 & 52 \\
\hline
\end{tabular}

Джерело: складено автором за даними Global Competitiveness Index 2019 [1]

Як видно із даних таблиці, переважна більшість оціночних показників в аналізованому періоді покращувалася. А якщо й погіршувалася, то в незначній мірі. При цьому, кінцевий субіндекс розвитку інфраструктури постійно погіршується. Причинами такого викривлення показників, на наш погляд $є$ різниця в динаміці розвитку транспортних підприємств в аналізованих країнах. Тобто, обсяги інвестицій у систему транспорту країни відносно обсягу ВВП в Україні $є$ переважно значно нижчими ніж в інших країнах. Особливо неприємно вражає відставання України за аналізованими показниками від тих країн, що прийнято вважати розвиненими приблизно на тому ж рівні - Грузії та Румунії.

Важливою складовою розвитку транспортних підприємств кожної країни $є$ наявність функціональної системи транспортної та складської логістики на загальнонаціональному рівні. Для оцінки даного показника можемо скористатися рейтингом Світового банку Індекс ефективності логістики. За даним показником Україна посідає 66 місце із 160 досліджуваних країн із показником 2,83 бали (табл. 2).

За цим рейтингом Україна опинилася між Сербією та Сгиптом, а серед країн пострадянського простору стала третьою після Естонії (36 місце) і Литви (54 місце). Лідерами 3 логістики є Німеччина, Швеція, Бельгія, Австрія і Японія. В даному рейтингу серед аналізованих країн Україна знов відстає від Румунії, але випереджає Грузію. Цікаво також відмітити високий рівень розвитку логістики в Польщі, що зумовлено, на нашу думку тим, що саме в цій країні утворено кілька загальноєвропейських диспетчерських центрів із вантажних автоперевезень робота яких грунтується на застосуванні технологій трекінгу, системи глобального позиціонування (GPS) та супутникової навігації, тобто діджиталізації автоперевезень. 
Таблиця 2. Рейтинг ефективності логістики у 2018-2019 році

\begin{tabular}{|c|c|c|c|c|c|c|c|c|c|}
\hline Країна & Показник & 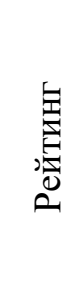 & 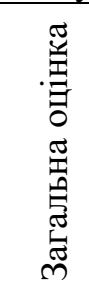 & 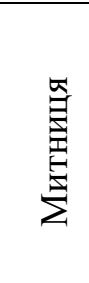 & 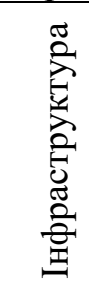 & 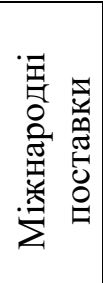 & 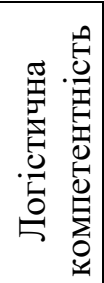 & 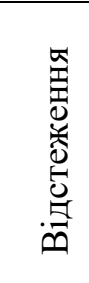 & 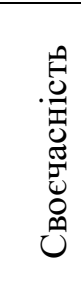 \\
\hline Литва & & 54 & 3.02 & 2.85 & 2.73 & 2.79 & 2.96 & 3.12 & 3.65 \\
\hline Туреччина & & 47 & 3.15 & 2.71 & 3.21 & 3.06 & 3.05 & 3.23 & 3.63 \\
\hline Грузія & & 119 & 2.44 & 2.42 & 2.38 & 2.38 & 2.26 & 2.26 & 2.95 \\
\hline Польща & & 28 & 3.54 & 3.25 & 3.21 & 3.68 & 3.58 & 3.51 & 3.95 \\
\hline Україна & & 66 & 2.83 & 2.49 & 2.22 & 2.83 & 2.84 & 3.11 & 3.42 \\
\hline Румунія & & 48 & 3.12 & 2.58 & 2.91 & 3.18 & 3.07 & 3.26 & 3.68 \\
\hline Росія & & 75 & 2.76 & 2.42 & 2.78 & 2.64 & 2.75 & 2.65 & 3.31 \\
\hline
\end{tabular}

Джерело: складено автором за даними Logistic Performance Index. The World Bank [2]

Високі показники в даному рейтингу Туреччини зумовлені активним розвитком вантажних портів за рахунок аналогічних інструментів, що дозволить оптимізувати їх пропускні функції та скоротити терміни перебування суден на рейді в територіальних водах країни, очікуючи своєї черги на розвантаження чи завантаження. Судновласники та власники вантажів за умови наявності альтернативи іноді обирають саме порти Туреччини або Грузії замість Українських через недосконалу логістику та корумпованість органів митниці. Таким чином, впровадження інформаційних інструментів у логістиці також є формою діджиталізації транспортних підприємств. Впровадження таких інновацій потребує суттєвих інвестицій з боку власників транспортних підприємств та державної підтримки, дослідження яких допоможе встановити основні напрямки розвитку, що обрані бізнесом та владою.

За оцінками експертів авторитетної консалтингової агенції PricewaterhouseCoopers основним напрямком інвестування коштів у сфері транспорту в найближчі п'ять років буде покращення якості доріг та розвиток залізничного транспорту. Лідерами за обсягами вкладених коштів будуть країни Азіатсько-Тихоокеанського регіону - близько \$8,3 трлн. Значно менше вкладатимуть США та Канада (\$1,7 трлн) та країни Західної Європи (\$1,5 трлн). Інвестиції ж країн інших регіонів не перевищуватимуть $\$ 1$ трлн з огляду на низький рівень економічного розвитку. Однак, якщо порівнювати темпи приросту витрат у сферу транспорту та їх співвідношення із рівнем розвитку економіки та ВВП, то лідерами стануть країни зі значно нижчим рівнем розвитку: країни південної Африки та Латинської Америки [3]. На жаль, України серед них немає.

Стратегічні напрямки розвитку транспортних підприємств зумовлюються виявленими проблемами сучасного стану. Міністерством інфраструктури України окреслено наступні проблеми розвитку транспорту:

- 90\% доріг в Україні потребують поточного чи капітального ремонту, який активно розпочато саме у 2019 році;

- найвищий рівень смертності на дорогах в Свропі;

- застарілість пересувного складу автобусних перевезень (автобуси дрібного класу мають середній вік 8-10 років, а великого - понад 15);

- зношеність пересувного складу залізничного транспорту понад 85\% при середньому віці локомотивів понад 40 років;

- низька залученість населення в авіаперевезення; неймовірно низька кількість та завантаженість внутрішніх рейсів;

- невизначеність перспектив розвитку значної кількості аеропортів (близько 20);

- використання потенціалу водного річкового транспорту лише на $3 \%$, а їх частка у транспортній системі складає $0,9 \%$, через обміління річок та зруйнованість причалів i річкових вокзалів.

При цьому, розвиток транспорту може стати одним із стимулюючих факторів економічної системи країни. Будівництво нових доріг шляхом розміщення державного замовлення дозволить створювати робочі місця, наростити пасажиро- та вантажопотік в країні. 
Розвиток транспортної інфраструктури сприятиме залученню інвестицій та зростанню привабливості Українських транспортних коридорів. Мультиплікативний вплив на економіку реалізується в частині зростання обсягів виробництва в реальному секторі економіки та підвищення конкурентоспроможності вітчизняних товарів.

Світовий досвід розвинених країн свідчить, що транспортні підприємства можуть стати локомотивом розвитку економіки, але для цього і самі потребують додаткових стимулів поступу. На сьогодні територія ЄС в достатньому обсязі забезпечена автошляхами та елементами інфраструктури подорожей, як пасажирів, так і вантажів. Однак, вже у 2012 році Всесвітня рада підприємців зі сталого розвитку (World Business Council for Sustainable Development) спільно 3 представниками гігантів транспортного бізнесу такими як Boeing, Toyota, PricewaterhouseCoopers, ArcelorMittal та інші презентували стратегічний план розвитку «Бачення 2050: новий порядок денний для бізнесу».

У 2011 році силами державних аналітичних установ ЄС розроблено власну конкретизовану стратегію розвитку транспортних підприємств континентального регіону: Біла книга Європейської Комісії «План розвитку єдиного європейського транспортного простору на шляху до конкурентоспроможної та ресурсоефективної транспортної системи». Дана стратегія передбачає:

- переведення всіх видів перевезень на всій території Європи, в т.ч. особистих засобів, на електротранспорт, тобто діджиталізація самої техніки транспортних підприємств;

- мінімізувати (оптимально - звести до нуля) смертність на дорогах $\mathrm{CC}$ за рахунок поширення нових, в т.ч., але не виключно, високотехнологічних інструментів попередження та обмежень на дорогах, створення безпечних умови руху та самих транспортних засобів;

- вдосконалення транспортної інфраструктури $€ C$ : будь-яка особа повинна мати можливість за пів години дістатись Транс'європейської транспортної мережі.

Увага всього світу на сьогодні прикута до розвитку технології Hyperloop: надшвидкісних поїздів. На сьогодні дана технологія ще перебуває на стадії експерименту, однак угоди про стратегічну співпрацю в частині з Hyperloop Transportation Technologies вже уклали Франція, Словаччина, Австрія, Угорщина, ОАЕ. Діяла така угода і в Україні, починаючи з 2018 року. За умови вдалого розвитку експериментальних технологій, Українська угода передбачала побудову в країні 11 гілок міжміського сполучення до 2050 року, 5 з них вже до 2030 року. Окрім того, будівництво Нyperloop в Україні вимагало створення додаткової інфраструктури: будівництва Smart-road, тобто діджиталізації автоперевезень та будівництво Tesla Gigafactory з виробництва акумуляторних батарей та сонячних панелей, що повинні були забезпечувати функціонування нових доріг та самого тунелю Hyperloop.

Угода про співпрацю Hyperloop Transportation Technologies 3 урядами країн СС передбачає будівництво тунелей даного виду транспорту, що зможуть з'єднати Відень (Австрія), Братиславу (Словаччина), Будапешт (Угорщина). В подальшому, за умови вдалої співпраці стане можливим з'єднання й інших європейських столиць даним високотехнологічним, діджиталізованим видом транспорту. В Об'єднаних Арабських Еміратах у 2019 році розпочалося будівництво експериментального тунелю Нyperloop довжиною 35 кілометрів. Перший такий тунель розташований на території США та має довжину близько 500 метрів.

На жаль, у 2019 році партнерство уряду України та Hyperloop Transportation Technologies зупинено. Тобто, в нашої країни був шанс доєднатися до передової світової спільноти в частині діджиталізації та започаткування нового етапу розвитку транспорту високошвидкісної ери, що виходить за рамки базового розуміння та сприйняття. Однак, зважаючи на неготовність вітчизняної економіки до таких глобальних проектів, цю можливість, сподіваємось - тимчасово, втрачено.

Розвиток вітчизняної транспортно-логістичної системи відбувається згідно Національної транспортної стратегії до 2030 року, важливим пріоритетом якої є розбудова безпечного для суспільства, екологічно чистого та енергоефективного транспорту. На сьогодні транспортний і логістичний потенціал України сформувався під впливом вигідного транзитногеографічного розташування, наявності виходу до двох морів та потужної системи трубопровідного транспорту. Система автомобільних та залізничних перевезень поступово розвивається та має хороші перспективи, зважаючи на поступове зростання товарообігу, як в середині країни, так і на зовнішньому ринку. Дещо відстає динаміка перевезення вантажів авіаційним транспортом, зважаючи на їх високу вартість та складність. Катастрофічно низькою, 
на наш погляд є завантаженість річкового транспорту України, яка може складати близько 50 млн тон на рік вже сьогодні, а в перспективі - 80 млн. тон. Крім того, саме такі перевезення $\epsilon$ найбільш енергоефективними та екологічними (табл. 3).

Таблиця 3. Обсяг перевезення вантажів в Україні, млн. тон

\begin{tabular}{|l|c|c|c|c|c|c|}
\hline \multirow{2}{*}{ Вид транспорту } & \multicolumn{7}{|c|}{ Роки } \\
\cline { 2 - 7 } & 2014 & 2015 & 2016 & 2017 & 2018 & 2019 \\
\hline Транспорт загалом & 1623 & 1474 & 1543 & 1597 & 1644 & 1579 \\
\hline Залізничний & 386 & 350 & 343 & 339 & 322 & 313 \\
\hline Морський & 2,8 & 3,2 & 3,03 & 2,2 & 1,8 & 2,1 \\
\hline Річковий & 3,1 & 3,1 & 4,6 & 3,6 & 3,7 & 3,9 \\
\hline Автомобільний & 1131 & 1021 & 1086 & 1122 & 1206 & 1147 \\
\hline Авіаційний & 0,78 & 0,69 & 0,74 & 0,82 & 0,99 & 0,92 \\
\hline Трубопровідний & 99 & 97 & 107 & 115 & 109 & 112,6 \\
\hline
\end{tabular}

Джерело: складено автором за даними Державної служби статистики [4]

Отже, транспортно-логістична система охоплює не лише парк безпосередньо транспортних засобів, транспортні шляхи, а і їх інфраструктуру, методи транспортування, перевізників, оптимальні маршрути, складську систему тощо. Узагальнивши інформацію про стан окремиї складових, можемо сформулювати основні проблеми транспортного сектору України:

- загальна корумпованість в країні;

- недосконалість нормативно-правого забезпечення та неефективна пріоритетність заходів державної підтримки;

- застарілість, технологічна й екологічна відсталість транспортних засобів та інфраструктури;

- низька якість транспортних та логістичних послуг;

- недостатність інвестицій та реінвестицій, несприятливий інвестиційний клімат в галузі.

Згадана вище Національна транспортна стратегія передбачає комплекс заходів із розвитку транспортно-логістичної системи, зокрема: будівництво Smart-road, будівництво Tesla Gigafactory 3 виробництва акумуляторних батарей та сонячних панелей, співробітництво із Hutchison Ports, DP World, General Electric, Bombardier, Tesla, Ryanair, залучення \$60 млрд інвестицій, 70\% нових поштових послуг на ринку тощо. Взагалі, плани даної стратегії дуже амбітні: 50 працюючих аеропортів на території України, котрі будуть обслуговувати 350 напрямків, в тому числі внутрішніх; застосування у сфері громадського транспорту виключно електричних транспортних засобів та його максимальну діджиталізацію; будівництво концесійних доріг-автобанів; повне оновлення локомотивів, вагонного парку та перехід на європейський стандарт колій; збільшення обсягів річкових перевезень та посилення ролі портів Чорного моря у міжнародному транспортному просторі.

Для досягнення таких цілей виключно планування і декларативних програм розвитку недостатньо, необхідні конкретні кроки та заходи. До них, на наш погляд, варто віднести:

- комплексне оновлення матеріально-технічної бази перевезень, котре зумовлюється державним регулюванням (вимоги та норми до стану транспортних засобів усіх видів);

- максимальна діджиталізація та залучення логістичних процесів у цифрове середовище 3 перспективою утворення BigData та управління нейромережами;

- зростання якості транспортно-логістичних послуг на підставі державної стандартизації;

- модернізація та спрощення митного обслуговування;

- створення загальнодержавного транспортного пулу для налагодження ефективної комунікації між перевізниками та представниками влади тощо.

Висновки. Транспортна система України має значний потенціал розвитку, котрий зумовлений значною просторовою протяжністю країни, іiі вигідним територіальним розташуванням та зростанням обсягів внутрішньої і зовнішньої торгівлі. На тлі світової вірусної пандемії обсяги пасажиропотоків набувають специфічного викривлення у 2020 році, тому їх динамічний аналіз на сьогодні не може дати достовірного уявлення про стан галузі. На жаль, не зважаючи на суттєвий потенціал, стан транспортного сектору залишається плачевним, як за 
внутрішніми, так і за світовими оцінками. Стан окремих елементів транспортної системи України $€$ значно гіршим ніж в країнах, що мають близький рівень економічного розвитку. Відповідно, сам транспортний сегмент може стати тою рушійною силою, котра дасть поштовх до зростання рівня життя в країні та іiі економічного благополуччя. Плани Уряду в частині транспортного сектору $є$ дуже амбітними та перспективними, але, на жаль, за часту носять декларативний характер.

\section{REFERENCES}

1. The GlobalCompetitiveness Report. 2019. World Economic Forum. URL: http://www3.weforum.org/docs/WEF_TheGlobalCompetitivenessReport2019.pdf $\quad$ (accessed: $\quad 01$, November, 2020).

2. Logistic Performance Index. The World Bank. URL: https://lpi.worldbank.org/international/global/2018.\%202019 (accessed: 02, November, 2020).

3. Global M\&A in the transport and logistics industry in 2019. PricewaterhouseCoopers. URL: https://www.pwccn.com/en/industries/transportation-and-logistics/publications/global-ma-in-the-transportand-logistics-industry-in-2019.html (accessed: 03, November, 2020).

4. Staty 'sty chna informaciya. Transport. Derzhavna sluzhba staty`sty 'ky`. [Statistical information. Transport. State Statistics Service]. URL: http://www.ukrstat.gov.ua/operativ/operativ2018/tr/tr_rik/xls/op_vant_vt_u.xlsx (accessed: 04, November, 2020).

5. On approval of the National Transport Strategy of Ukraine for the period up to 2013. Cabinet of Ministers of Ukraine. Order of May 30, 2018 № 430-r. URL: https://zakon.rada.gov.ua/laws/show/430-2018\%D1\%80\#Text (accessed: 06, November, 2020).

6. Drive Ukraine 2030: yakoyu bude ukrayins'ka infrastruktura cherez 12 rokiv. Infohrafika. [Drive Ukraine 2030: what will be the Ukrainian infrastructure in 12 years. Infographics]. Espreso.tv. URL: https://espreso.tv/article/2018/06/29/drive_ukraine_2030_yakoyu_bude_ukrayinska_infrastruktura_cherez_ 12_rokiv_infografika (accessed: 10, November, 2020). 